\title{
Almanak Menara Kudus: Study of Hisāb Results in 1990 until 2019
}

\author{
Ahmad Fauzi \\ Sekolah Tinggi Agama Islam Walisembilan Semarang - Indonesia \\ e-mail:ahmad_fauzy@ymail.com
}

\begin{abstract}
Almanak Menara Kudus is the work of KH. Turaichan which is done by the method of hisāb qat'i i. The results of the almanac, especially the initial determination of Shawwal, are sometimes different from the Government and other Islamic calendars. However, after the death of KH. Turaichan, Almanak Menara Kudus held by Sirril Wafa -son of KH. Turaichan- has never been different from the results of the Government calculations and other Islamic calendars. This study discusses changes in the calculation methods of the two figures from 1999 to 2019. This study is qualitative in the literature method and comparative analysis. This study concluded that in Almanak Menara Kudus, between KH. Turaichan and Sirril Wafa, there was no changes in the method. It's just that there are developments in the Sirril Wafa era, those are corrections to the horizontal parallax, refraction, and semi-diameter, so that the results are more accurate with a difference of about $1^{\circ}$.
\end{abstract}

\section{[1}

Almanak Menara Kudus merupakan karya KH. Turaichan yang dilakukan dengan metode hisāb qațīi. Hasil dari almanak tersebut, khususnya penentuan awal Syawal, terkadang berbeda dengan Pemerintah dan kalender Islam lainnya. Namun demikian, sepeninggal KH. Turaichan, Almanak Menara Kudus yang dipegang oleh Sirril Wafa anak KH. Turaichan- tidak pernah berbeda dengan hasil penghitungan Pemerintah dan kalender Islam lainnya. Penelitian ini membahas perubahan metode penghitungan kedua tokoh tersebut dari tahun 1999 sampai 2019. Penelitian ini bersifat kualitatif dengan metode kepustakaan dan Analisa komparatif. Penelitian ini menyimpulkan bahwa dalam Almanak Menara Kudus, antara KH. Turaichan dan Sirril Wafa, tidak ada perubahan metode. Hanya saja terdapat pengembangan pada era Sirril Wafa, yaitu koreksi pada horizontal parallax, refraksi, dan semi diameter, sehingga hasilnya lebih akurat dengan selisih sekitar $1^{\circ}$.

Keywords: Almanak Menara Kudus; KH. Turaichan; Sirril Wafa; hisāb 
Ahmad Fauzi

\section{Introduction}

Almanac is a system of calculations that aims to organize time in a certain period. The form of the almanac is quite a lot, even in calculations it has its own cycle rules. In addition there are also almanacs who have their own characteristics. ${ }^{1}$ There are Almanacs that use the calculation of the Sun (solar), the Moon (lunar) and the combination of both the Sun and Moon. In a modern context, a calendar is a mean of organizing time precisely and effectively and a history recorder. While for religious people-especially Muslims, the calendar is a mean of determining religious days (worship) easily and well. ${ }^{2}$

In Indonesia there is a famous almanac, Almanak Menara Kudus which is a monumental work of an ulama named KH. Turaichan (Yi Tur). He was a wise man whose expertise in science was undoubtedly by Indonesian astronomy experts. Once, the work was one of the references in determining the beginning of the month of Hijriyah by the Ministry of Religion. He has a characteristic of the determination and conviction of the results of his calculations of any determination and anyone. One of them is boldly declaring that the Qibla direction of the al-Aqsha Mosque of Menara Kudus must be straightened because it faces too far south. Though this mosque was founded by one of Walisongo's Sunan Kudus. This is one example of his determination to uphold astronomy science. ${ }^{3}$

KH. Turaichan passed away on $20^{\text {th }}$ August 1999 in the age of $84 .^{4}$ Then his expertise was continued by his son named Sirril Wafa who was the successor in the field of Astronomy science and currently holds the authority in the making of Almanak Menara Kudus.

Almanak Menara Kudus is an almanac that uses the circulation of the moon (qamariyah) or lunar system and includes Almanac Hijri (Islamic). According to Sirril Wafa, Almanak Menara Kudus was composed by KH. Turaichan

\footnotetext{
${ }_{1}^{1}$ Slamet Hambali, Almanak Sepanjang Masa Sejarah Sistem Penanggalan Masehi, Hijriyah dan Jawa (Semarang: Program Pasca Sarjana IAIN Walisongo, 2002), 3.

${ }^{2}$ Arwin Juli Rakhmadi Butar-butar, Kalender Sejarah dan Arti Pentingnya dalam Kehidupan (Semarang: Bisnis Mulia Konsultama, 2014), 2.

${ }^{3}$ Syaiful Mujab, "Konsep Penentual Awal Bulan Hijriyah Menurut KH. Turaichan Adjuri” (Pasca IAIN Walisongo, 2010), 1.

${ }^{4}$ Susiknan Azhari, Hisab \& Rukyah (Wacana untuk Membangun Kebersamaan di Tengah Perbedaan) (Yogyakarta: Pustaka Pelajar, 2007), 156.
} 
Adjhuri using hisāb qațizi. The data used in the calculation of the beginning of the month of the Hijrah by KH. Turaichan Adjhuri is data derived from alMațla' al-Sa'îd and the calculation process refers to al-Khuläșah al-Wäfiyyah.

If we look carefully at Almanak Menara Kudus, we can know that this almanac is not just an ordinary calendar, but there are a lot of information contained in it, some of those are: 1) Almanak Menara Kudus does not only display the Christian and Hijri calendar, but also provides information on the Javanese calendar (Pranotowongso) and the market day. 2) The markaz center for calculating the Hijri calendar is in Central Java. 3) The data on calculating the beginning of Hijriyah each month are displayed. 4) It contains data on eclipse events (moon and sun). 5) There are also 5 prayer times for Yogyakarta, Semarang, and surrounding areas. 6) It displays data about correcting the Qibla direction, namely on: May 28 at 16:18 WIB and July 16 at 16:27 WIB. It is the right time to straighten the Qibla because at that moment the sun is right above the Ka'bah, the shadow of the object in the flat plane when it is right leads to the Ka'bah.

$\mathrm{KH}$. Turaichan often disagrees with the Government or with one of the Islamic organizations, namely Pengurus Besar Nahdlatul Ulama (PBNU) in the determination of the feast. It is possibly because of the differences in the hisāb method, data or criteria used. He is a persistent and unswerving ulama in holding the results of his ijtihād.

He is a charismatic and influential scholar in society; especially the Muslim community in Central Java and especially for the people of Kudus. They were very fanatic about the initial determination of the Hijri month in Almanak Menara Kudus. The difference in determining the beginning of Shawwal was seen, for example, in $1990.5 \mathrm{KH}$. Turaichan died on Saturday night 9 Jumadil Awal 1420H/20 August 1999 M and left two of his favorite santri, namely KH. Noor Ahmad in Jepara and KH. Rosyidi in Kudus. ${ }^{6}$

Since the death of KH. Turaichan in 1999 until 2019 the determination of hisāb Almanak Menara Kudus was held by Sirril Wafa (his son). Seeing the advantages of Almanak Menara Kudus, the author is interested to discover the system used by KH. Turaichan in the almanac. Moreover, after the death of KH.

${ }^{5}$ Mujab, “Konsep Penentual Awal Bulan Hijriyah Menurut KH Turaichan Adjuri.”, 10-11.

${ }^{6}$ Azhari, Hisab \& Rukyah (Wacana untuk Membangun Kebersamaan di Tengah Perbedaan), 156. 
Ahmad Fauzi

Turaichan, how the development of the system was used in Almanac Menara Kudus, by looking at the technological advances which of course many new methods that the results are very accurate. From the problems mentioned above, the author is interested in reviewing and comparing the Almanak Menara Kudus in the era of KH. Turaichan and in his successors, starting from 1990 to 2019

\section{Hisāāb Criteria in Astronomy Science Criteria for Hisāāb}

Initially determining the begining of the hijri month is by seeing hilāl. After the development of science, Moslems use hisāb (astronomy) as a mean to determine the beginning of the hijriah month. In hisāb, there are two ways to determine the beginning of hijriyah, those are hisāb'urfi and hisāa haqiqui.

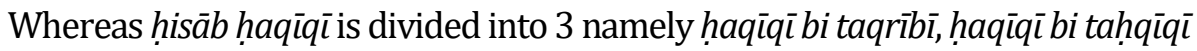
and haquīì bi tadqīqī (contemporary). ${ }^{7}$

Systematically madhhab hisāb in Indonesia can be divided into two major groups:

\section{Hisāb Urfi}

Hisāb'ürfic is a calculating system in determining the beginning of the lunar month based on the time of the moon average circulation around the earth which takes a period of 29 days 12 hours 44 minutes and 3 seconds. It is called hisāb'ürfi because this system stipulates that for each odd month is 30 days old and the even month is 29 days except the $12^{\text {th }}$ month (Zulhijjah) in leap years is set to be 30 days. In practice, this system no longer observes the position of the moon but only uses certain methods which are permanently irregular, unlike the system of calculating the Christian calendar. ${ }^{9}$

This hisāb basically refers to the following principles: 1) Determinating the beginning of the hijri, both the date and the month of the year, namely the 1 st

\footnotetext{
${ }^{7}$ Ahmad Ghazali, al-Dūr al-Anīq, fi Ma'rifah al-Hilāl wa 'l-Khusufayn bi al-Tadqīq (Madura: Lafal Lanbulan, n.d.), 4.

${ }^{8}$ Among the books of hisāb discussing and adhering to this system are Badī'ah al-Mithāl fi Hisāb alSinin wa al-Hilāl by Ma'shum bin Ali al-Maskumambangi, Syamsul hilal Volume 1 by Noor Ahmad SS, Ilmu Falak by Salamun Ibrahim, The Muslim and Christian Calenders by G.S.P. Freeman Grenville, Almanak Sepanjang Masa by Slamet Hambali.
}

${ }^{9}$ Muslih Ade Mansur, Belajar Ilmu Falak2 (Cilacap: Ihya Media, 2011), 39. 
day of Muharram $1 \mathrm{H}$, to coincide with Thursday, July 15, 622 AD or Friday, July 16, 622 AD. 2) In one year the age is $35411 / 30$ days so that in 30 years or one cycle there are 11 years long and 19 years short. 3) Long years of age 355 days and short years are 354 days. 4) Long years are in the rows of the $2^{\text {nd }}, 5^{\text {th }}$, $7^{\text {th }}, 10^{\text {th }}, 13^{\text {th }}, 16^{\text {th }}, 18^{\text {th }}, 21^{\text {st }}, 24^{\text {th }}, 26^{\text {th }}$ and $29^{\text {th }}$ years while the other rows are short years. 5) The odd months are 30 days while the long months are 29 days with information for the 12-year long month (Dhulhijjah) set at 30 days. ${ }^{10}$

\section{Hisāba Haqūqū}

Hisāb haqiqui is a system of calculating the beginning of the lunar month based on the position of the moon either associated with the ecliptic plane on the celestial sphere or the horizon on the surface of the earth. ${ }^{11}$ The state of the moon is at least related to the time of $i j t i m \bar{a}^{\prime}$ with the sun, its height at sunset and its Azimuth difference from the sun at the time of the sunset.12

This hisāb haqīqū can be divided into three types. 1) Hisāb haquiqù taqrībī which is known as the classical or traditional method. It is called hisāb haqiqqi taqrībi because the results of the calculation show a level of more or less. In determining the position of the hilāl of the beginning month, this method determines first when ever ijtimä' haqiqu $\mathbf{~ s h o w s ~ i j t i m a ̈ ' ~ o n ~ a v e r a g e , ~ t h e n ~ t h e ~ t i m e ~}$

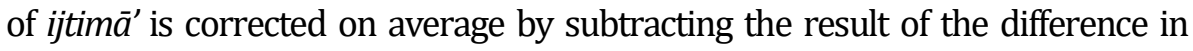
velocity of the moon leaving the sun. The distance between the moon and the sun is known by correcting the position of the moon and sun on average three times. Then the height of the hilāl is determined by dividing the difference between the time of sunset and the time of Ijtimä'. Among the methods included are Sulam al-Nayyirayn, Fath al-Ra'üf al-Mannān and Qawā'id al-Astrūnūmiyah, Tadhkīrah al-Ikhwān, Bulūgh al-Wațār, Risālah al-Qamarayn, Risālah alAstrūnūmiyah, Tashīl al-Mithāl,Jadāwil al-Astrūnūmiyah, Shams al-Hilāl Volume 2, Awā'il al-Astrūnūmiyah. ${ }^{13}$ 2) Hisāb haqiqui tahqīqū. This method is a method between classical and modern, besides using modern mathematical rules, also in calculating hilāl height of the beginning month, it first determines the average

\footnotetext{
${ }^{10}$ Kemenag, Ephemeris Hisab Rukyat 2014 (Jakarta: Kemenag RI, 2014), 95-96.

${ }^{11}$ Ade Mansur, Belajar Ilmu Falak 2, 40-41.

${ }^{12}$ Abd Salam Nawawi, Ilmu Astronomy Cara Menghitung Waktu Salat Arah Kiblat dan Awal Bulan (Sidoarjo: Aqaba, 2010), 59.

${ }^{13}$ Ade Mansur, Belajar Ilmu Falak 2, 41.
} 
position of the moon and the sun on the celestial sphere at the end of the moon, then it will be corrected about five times and calculated its parallax and refraction. Included in this hisāb are the books of al-Khuläșah al-Wāfiyah, Ittifāq Dhatilbayn, Hissb Haqīqū, Nūr al-Anwār, al-Mațla' al-Sa'î̀, Manāhij al-Hamìdiyah, Bī'ah al-Mithāl, Muntahā Natāíi al-Aqwāl, and Hisāb Haqūqü Kiai Wardan Diponingrat 3) Contemporary hisäb. This hisäb method is basically the same as the hisāb haquiq $\bar{\imath}$ tahqīqi method mentioned above, which prioritizes modern mathematical rules, but uses considerable and thorough correction and uses contemporary astronomical data and contemporary mathematical rules, the method includes Ephemeris, New Comb, and Nautical Almanacs. ${ }^{14}$

\section{Almanak Menara Kudus}

Almanak Menara Kudus consists of two eras, the first is the era of $\mathrm{KH}$. Turaichan, which began to be made until he died in 1999 and the second was the Sirril Wafa era which has bees began in 2000 until now. Turaichan Adjhuri Asy-Syarofi is a figure of a 'charismatic' ulama who is an Astronomy scientist. He once attended the pesantren of KH. Abdul Djalil Hamid in Kudus. He was born in Kudus on March 15, 1915 M/1334 H and passed away on Friday, August 20, 1999 AD to coincide with the $8^{\text {th }}$ Final Rabiul 1420 H. Yi Tur, thus his familiar greeting was recorded as one of the $16^{\text {th }}$ descendants of Sunan Kudus, one of the people who spread Islam in Java.

The perseverance of Yi Tur on astronomy emerged from childhood to adulthood. According to the information from several ulama in Kudus, while he was still young, Yi Tur was a smart child. It has been proven since he was 15 years old that he was able to teach the top level of the Tasfiqut Tulab Salafiyah (SFS) madrasa in Kudus. His reputation as an expert in astronomy has been heard since the Japanese era. He was often asked to calculate the beginning and the end of Ramadann. Young Turaichan was compelled to compile the $1945 \mathrm{M} / 1364 \mathrm{H}$ almanac which was later printed by the Menara Publisher. Since then the calendars made by the clerics who have learned autodidactly are called Almanak Menara Kudus (AMK).

In $1951 \mathrm{M} / 1371 \mathrm{H}$ the date of his work became a reference for most NU people throughout Indonesia. Through his works, Yi Tur has made a positive

\footnotetext{
${ }^{14}$ Ade Mansur, 41-2.
} 
contribution to NU and the Government, especially in the field of dating. Yi Tur is increasingly known by public, especially when it was approaching the fasting month, to determine the date of 1st Shawwāl and 'Īd al-Aḍāa. The product of Almanak Menara Kudus, which has become Yi Tur's monumental work, was first published by Masykuri Kudus Printing in 1942 AD/1361 AD and later since 1950 M/1370 H until now, published by Menara Kudus. ${ }^{15}$

Based on the results of interview with Sofiyanto (2014), a staff member of the printing of Menara Kudus, that the printing of Menara Kudus only prints calendars based on hisāb, KH. Turaichan or his successors, never prints calendars based on other hisāb. Then after Yi Tur died, the Almanak Menara Kudus was continued by Sirril Wafa. Sirril Wafa who is more familiar with Pak Sirril is an Astronomy expert who was born in Kudus, Central Java on March 18,1960 . He was educated in a religious environment. Since he was a child, he was equipped with a fairly mature religious education by the clerics, especially from his father who was also known as the maestro of the Holy Celestial Expert, KH. Turaichan Adjhuri Ash-Syarofi and also a descendant of Raden Ja'far Shodiq or often known as Sunan Kudus. The husband of Dra. Linitaria resides on Jl. Raya Ciputat, Parung, Bojongsari Village RT 02/08 No 10 A Depok 16516, along with three children named Achla Ilfana, Imtiyaz Fawai'da and Alvin Nawal Syarof.

He began his formal education at MI Tasywiquth Thullab Salafiyyah Kudus and graduated in $1974 \mathrm{M}$. After studying at the elementary or MI level, then he continued at MTs Tasywiquth Thullab Salafiyyah Kudus and finally graduated in 1977, then continued to MA Tasywiquth Thullab Salafiyyah Kudus, who finally graduated in 1980 . He could say that he was istiqomah in taking his education in the Tasywiquth Thullab Salafiyyah Madrasah, which is now known as TBS, in which his own father was included as one of the leaders.

In addition to formal study, Sirril Wafa also studied bookkeeping and trade counting in Kudus from 1978 to 1979, and he was also known to be diligent in studying the books of the salaf, both in the house of the clerics and in every pengajian book in the mosques around Kudus. His Astronomy science expertise can be from the Tsanawiyyah bench starting from the hisāb'urfi method, hisāb

${ }^{15}$ Azhari, Hisab \& Rukyah (Wacana untuk Membangun Kebersamaan di Tengah Perbedaan), 156-7. 



KH. Abdul Bashir, K. Baihaqi, and from his own father KH. Turaichan Adjhuri.

In contrast to the tradition of the kiai in general, namely continuing his education to the Islamic boarding school, Mr. Sirril, this familiar term instead continued his education to a college in Jakarta precisely at IAIN Syarif Hidayatullah. Here he studied with experts in the field of Astronomy Science, one of which was Drs. H Mustajib, MA (late), and right in 1984 he officially held the title of bachelor of Sharia Faculty of UIN Syarif Hidayatullah in 1987 and finally his complete Bachelor obtained. After that he continued his Masters and S3 at the same almamater and got a master's degree in majoring in Islamic studies at UIN Jakarta.

His expertise in organizing was undoubted, he has shown this since the Supreme Court as the secretary of the OSIS PP MA TBS in the period 19781979. This activity encouraged him to take part in training. He has also participated in various trainings on celestial spheres, such as Diklat Hisab Rukyat Nasional level held by the Ministry of Religion Education and Training Center in Ciputat in 1992. Since 2000, due to his expertise in the field of astronomy, he was recruited to become a member of the Lembaga Falakiyah $P B N U$ and in 2000 he was appointed as deputy chairman of the Lembaga Falakiyah PBNU until now. His work in developing astronomy and his activity in various activities of hisāb ru'yat made him trusted as Chair of the Lembaga Hisab Rukyat Depok and a member of the Lembaga Hisab Rukyat Pusat. Besides being well-known as an astronomer he is also known as a charismatic cleric and 'ālim in the field of jurisprudence; therefore, he is trusted as a Member of the Central MUI Fatwa Commission.16

\section{Hisāa $b$ Thought on Early Month in the Era of KH. Turichan and Sirril Wafa Era}

The data used by KH. Turaichan on hisāb of the Hijriyah beginning is the data originating from the $M a t^{\prime} l \bar{a}^{\prime} a l-S a{ }^{\prime} \hat{l} d$ and the calculation process refers to the al-Khulāșah al-Wäfiyyah by KH. Zubair Umar Jailani. The data from Majmü'ah uses the longitude of Egypt, because the markaz of KH. Turaichan is in Semarang, so he changes the data according to the longitude of Semarang, which is $7^{\circ} 0^{\prime}$ and $\mathrm{BT} 110^{\circ} 24^{\prime}$.

16“Sang Penerus Falakyang Kharismatik dari Kota Santri,” 2015, 2-3. 
In an interview with Sirril Wafa, KH. Turaichan and KH. Zubair Umar Jailani often met and exchanged their thoughts in discussing about the beginning of the month. The system and process of the beginning of the month hisāb in alKhulāșah al-Wäfiyyah is to look for ijtimā'. By knowing ijtimā', it is the process of the beginning of the month. Ihis book only shows the system of calculating the beginning of the lunar month and does not set a standard at the beginning of the month. The process of looking for ijtimā' is to calculate tūl al-shams (longitude sun) and țül al-qamar (longitude moon) ${ }^{17}$ by knowing the calculation with this system, it will make it easier to implement ru'yah.

$\mathrm{KH}$. Turaichan also uses provisions in determining the beginning of the month, namely mațla' local rather than mațla' wilāyah al-hukm as used by the government. And also not mațla' which is used by Hizbut-Tahrir Indonesia (HTI) that uses the global mațla'. Mațla' used in Almanak Menara Kudus is Central Java with a center in Semarang. This use of local mațla is based on the hadith which is revealed by Kurayb.

Besides, KH. Turaichan also has a criterion in determining the beginning of the month in the Almanak Menara Kudus, that is, the main basis for the replacement of the new moon is hilāl must have a height of at least $2^{\circ}$. Ijtima $\bar{a}^{\prime}$ is also considered by $\mathrm{KH}$. Turaichan in determining the beginning of the hijri month, named ijtimä' qabl zawāl. Ijtimä' qabl zawāl is that the beginning of the month can be approved if ijtimä' occurs before the occurrence of zawāl.

The results of the interview with Sirril Wafa that hisāb in the Almanak Menara Kudus was the same, which is using the transplanting of the book Mațla' al-Sa'îd and using the work process with the book al-Khulāsah alWäfiyyah. Also with the criteria used. Even so he continued to adopt the development of the times by adding corrections to the nautical almanac and the ijtimä' calculated using astronomical alghorithm.

\section{The Results of the Early Month Hisāb in Almanak Menara Kudus}

From the results of hisāb Ramaḍān 1990-2019 (KH. Turaichan Era from 1990-1999 and Sirril Wafa Era from 2000-2019), it can be seen that in the Almanak Menara Kudus in 1990 until 2019 for the results of Ramaḍān hisāb in

\footnotetext{
17Zubair Umar al-Jailani, al-Khulāṣah al-Wāfiyyah fi al-Falak bi Jadwāl al-Lugharitmiyah (Surakarta: Melati, n.d.), 116.
} 
the era of KH. Turaichan (1990-1999) shows the height of the moon in the beginning of the month, nür al-hiläl beginning of the month and mukūth hilāl beginning of the month, as well as the determination of the $1^{\text {st }}$ Ramadān including the day, the market day and date but is does not show the ijtimä' of the end of the month both time and it does not show the final month height' tire. The results of Ramadian hisāb in the Sirril Wafa era (2000-2019) shows the height of the moon in the beginning of the month, nür al-hilāl of the beginning month, Mukūth hilāl of the beginning month, determination of the $1^{\text {st }}$ Ramadān both the day and the market day and displaying ijtimä' of the moon hight in the end of Sha bān in several years.

From the results of Shawwāl hisāb 1990-2019 on KH. Turaichan Era from 1990-1999 and Sirril Wafa Era from 2000-2019, it can be seen that in the Almanak Menara Kudus from 1990 to 2014 for the results of Shawwāl hisāb in the era of KH. Turaichan (1990 -1999) is to display the moon height in the beginning of the month, nür al-hilāl beginning of the month and muküth hilāl at the beginning of the month, and the determination of the $1^{\text {st }}$ of Shawwāl including the day, the market day and date but is does not show the ijtimä' of the end of the month both time and it does not show the final month height' tire. The results of Ramadiann hisāb in the Sirril Wafa era (2000-2019) shows the height of the moon in the beginning of the month, nür al-hilal of the beginning month, mukūth hilāl of the beginning month, determination of the $1^{\text {st }}$ Ramadān both the day and the market day and displaying ijtimā' of the moon hight in the end of Sha'bān in several years.

From the results of hisāb Dhulhijjah 1990-2014 (KH. Turaichan Era from 1990-1999 and Sirril Wafa Era from 2000-2019), it can be seen that in the Almanak Menara Kudus from 1990 to 2019 for the results of hisāb Dhulhiijjah in the era of KH. Turaichan (1990 -1999) is showing the height of the moon in the beginning of the month, nür al-hilāl beginning of the month and muküth hilāl at the beginning of the month, and the determination $1^{\text {st }}$ of day of Dhulhijjah both day and market day but not showing the ijtimä of the end of the month both time and date and not displaying the end of Dhulqa'dah already. The results of hisāb Dhulhijjah in the Sirril Wafa era (2000-2019) shows the height of the moon in the beginning of the month, nür al-hilāl at the beginning of the month, muküth hiläl at the beginning of the month, determination of the $1^{\text {st }}$ day of the month and market and displaying ijtima $\bar{a}^{\prime}$ the height of the last month of Dhulqa'dah in several years. 
Between the era of KH. Turaichan and the Sirril Wafa era there are comparable components, in Almanak Menara Kudus, those are:

\section{Place and Astronomical Data}

Determinating the beginning of the month of $\mathrm{KH}$. Turaichan in the Almanak Menara Kudus used data originating from the book of Mațla' al-Sa'îd and the calculation process using the book of al-Khulāsah al-Wäfiyyah. Based on the book, the data for the senior year uses Egyptian longitude, because the markaz of KH. Turaichan in Central Java is precisely in Semarang, in which it is was measured by the modern astronomical system using longitude Grenwich $0^{\circ}$, the longitude of Semarang is $110^{\circ} 24 \mathrm{BT}$.

The place data in Almanak Menara Kudus used by Sirril Wafa is still Semarang which if measured by the modern astronomical system uses longitude Grenwich $0^{\circ}$ longitude Semarang is $110^{\circ} 24^{\prime} \mathrm{BT}$ and its calculations still uses the book of al-Khulāșah al-Wäfiyyah added corrections.

The data above needs to be known to determine the research headquarters in detail. It aims to obtain accurate place data and will be very related to epoch. The data used in the Almanak Menara Kudus in determining the beginning of the month is the year data, month data, data, days, hour data and minute data that can be seen in the book al-Khulāṣah al-Wāfiyyah.

\section{Epoch}

Almanak Menara Kudus (AMK) uses the epoch headquarters of Semarang with longitude $110^{\circ} 24^{\prime}$. Whereas in the book al-Khulāșah al-Wāfiyyah uses the Mecca headquarters. The other epoch comparison of the haqiqi bi tahqiq method, can be seen in Table 1.

Table 1.

Comparison of Epoch

\begin{tabular}{lc}
\hline \multicolumn{1}{c}{ Method Haquīqi bi Tahqüq } & Epoch \\
\hline AMK Era KH. Turaichan & Semarang, Central Java \\
AMK Era Sirril Wafa & Semarang, Central Java \\
al-Khulāshah al-Wafiyyah & Mecca \\
Nūr al-Anwār (a student of KH. & Jepara \\
Turaichan) & \\
\hline
\end{tabular}


Ahmad Fauzi

\section{Process/Step}

The steps to calculate the initial determination of the month taken by Almanak Menara Kudus on KH. Turaichan Era is to follow the book of alKhulāșah al-Wäfiyyah. This method according to the author is following the medieval era that uses columns or rows and seems complicated and not easy especially for those who are not proficient in the field of Astronomy science. The steps for calculating the book al-Khulāṣah al-Wāfiyyah, can be seen in Table 2 .

\section{Correction}

Corrections of the KH. Turaichan era in Almanak Menara Kudus of the KH. Turaichan era are as found in the book al-Khulāșah al-Wäfiyyah but have not used the hiläl correction such as horizontal parallax, refraction, and semi-moon diameter (SD). While the Almanak Menara Kudus in the Sirril Wafa era has used parallax, refraction and semi-diameter of the Moon (SD). The following is a comparison table of the hisāb Almanak Menara Kudus in KH. Turaichan Era and Sirril Wafa Era.

Table 2.

Calculation steps in the book al-Khulāsah al-Wäfiyyah.

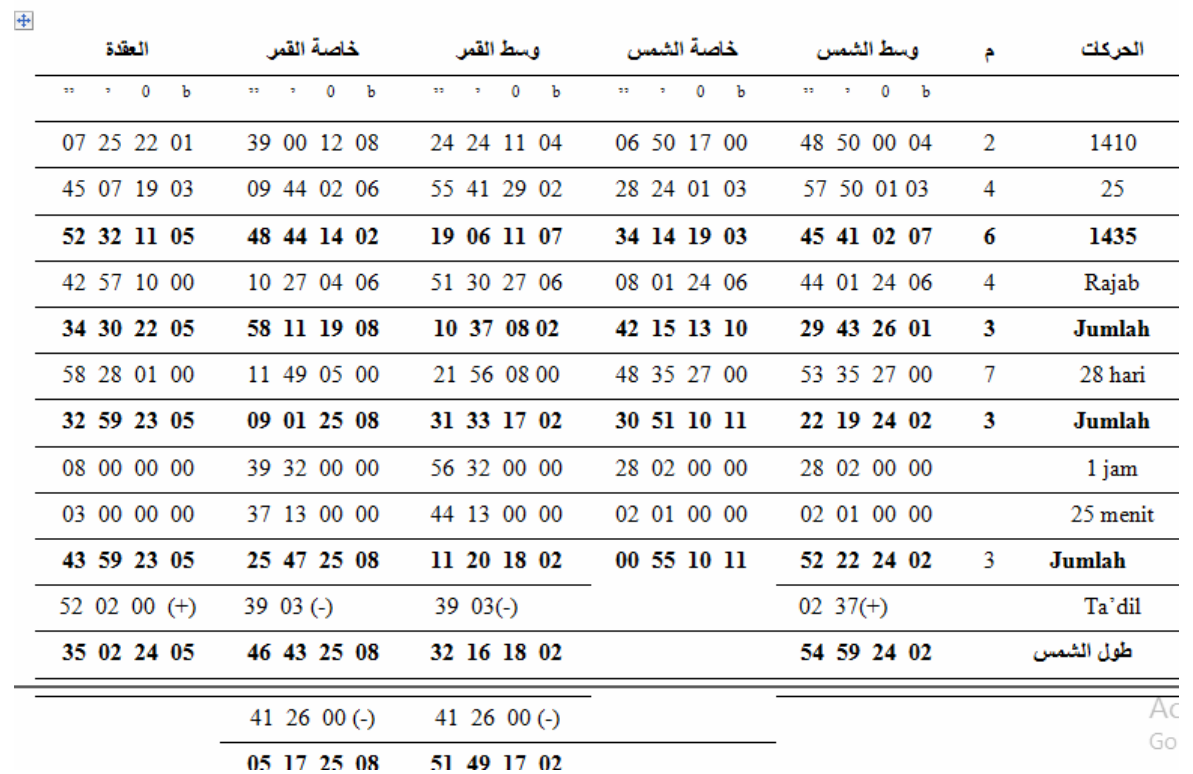


Table 3.

\section{Comparison Table of the Hisab Method}

\begin{tabular}{|c|c|c|c|}
\hline No. & Method Hisāa & $\begin{array}{c}\text { AMK } \\
\text { Era KH. Turaichan }\end{array}$ & $\begin{array}{c}\text { AMK } \\
\text { Era Sirril Wafa }\end{array}$ \\
\hline 1 & $\begin{array}{l}\text { Data and } \\
\text { Calculation }\end{array}$ & $\begin{array}{l}\text { Mațla' al-Sa'īd dan al- } \\
\text { Khulāșah al-Wäfiyyah }\end{array}$ & $\begin{array}{l}\text { Mațla'al-Sa'īd dan al- } \\
\text { Khulāșah al-Wāfiyyah }\end{array}$ \\
\hline 2 & Epoch & Semarang, Jawa Tengah & Semarang, Central Java \\
\hline 3 & Step & Step Classic (medieval) & Step Classic (medieval) \\
\hline 4 & Correction & No Correction & $\begin{array}{l}\text { horizontal parallaks, } \\
\text { refraktion, dan semi } \\
\text { moon diameter (SD) }\end{array}$ \\
\hline
\end{tabular}

Comparison of the results of hisāb in Almanak Menara Kudus between the era of KH. Turaichan and the Sirril Wafa era for the height of the moon's of Shawwāl, Ramadān and Dhulhijjah, the author took the example for years that had happened with the Government, PBNU and Muhammadiyah. The following is a comparison of the results of hisāb.

\section{Month of Shawwal}

From the Table 4 for the month of Shawwāl the comparison of the results of hisāb between Almanak Menara Kudus in the era of KH. Turaichan and the Sirril Wafa era there is a difference of about $1^{\circ}$.

Table 4.

\section{Comparison of the Results of Hisāb in the Month of Shawwāl}

\begin{tabular}{|c|c|c|c|c|}
\hline Year & $\begin{array}{c}\text { Almanak Menara } \\
\text { Kudus }\end{array}$ & $\begin{array}{c}\text { High Hilāl } 1 \\
\text { Shawwāl }\end{array}$ & Day & Date \\
\hline \multirow{2}{*}{$\begin{array}{l}1990 / \\
1410\end{array}$} & KH. Turaichan & $13^{\circ} 40^{\prime} 8^{\prime \prime}$ & \multirow{3}{*}{$\begin{array}{l}\text { Jum'at } \\
\text { Kliwon }\end{array}$} & \multirow{3}{*}{$27 / 04 / 1990$} \\
\hline & Sirril Wafa & $12^{\circ} 22^{\prime} 26.49^{\prime \prime}$ & & \\
\hline Info & difference & $1^{\circ} 17^{\prime} 41.51^{\prime \prime}$ & & \\
\hline \multirow[t]{2}{*}{1992} & KH. Turaichan & $10^{\circ} 26^{\prime} 4^{\prime \prime}$ & \multirow{3}{*}{$\begin{array}{l}\text { Ahad } \\
\text { Wage }\end{array}$} & \multirow[t]{3}{*}{$05 / 04 / 1992$} \\
\hline & Sirril Wafa & $9^{\circ} 18^{\prime} 51.48^{\prime \prime}$ & & \\
\hline Info & difference & $1^{\circ} 7^{\prime} 12.52^{\prime \prime}$ & & \\
\hline \multirow[t]{2}{*}{1993} & KH. Turaichan & $8^{\circ} 33^{\prime}$ & \multirow{3}{*}{$\begin{array}{l}\text { Kamis } \\
\text { Pon }\end{array}$} & \multirow[t]{3}{*}{$25 / 03 / 1993$} \\
\hline & Sirril Wafa & $7^{\circ} 30^{\prime} 1.47^{\prime \prime}$ & & \\
\hline Info & difference & $1^{\circ} 2^{\prime} 58.53^{\prime \prime}$ & & \\
\hline
\end{tabular}


Ahmad Fauzi

\begin{tabular}{|c|c|c|c|c|}
\hline \multirow{2}{*}{$\begin{array}{c}1994 / \\
1414\end{array}$} & KH. Turaichan & $9^{\circ}$ & \multirow{3}{*}{$\begin{array}{l}\text { Senin } \\
\text { Pahing }\end{array}$} & \multirow[t]{3}{*}{$14 / 03 / 1994$} \\
\hline & Sirril Wafa & $7^{\circ} 56^{\prime} 59.04^{\prime \prime}$ & & \\
\hline Info & Difference & $1^{\circ} 3^{\prime} 0.96^{\prime \prime}$ & & \\
\hline \multirow[t]{2}{*}{1998} & KH. Turaichan & $14^{\circ} 27^{\prime} 6^{\prime \prime}$ & \multirow{3}{*}{$\begin{array}{l}\text { Jum'at } \\
\text { Kliwon }\end{array}$} & \multirow[t]{3}{*}{$30 / 01 / 1998$} \\
\hline & Sirril Wafa & $13^{\circ} 14^{\prime} 15.36^{\prime \prime}$ & & \\
\hline Info & Difference & $1^{\circ} 12^{\prime} 50.64^{\prime \prime}$ & & \\
\hline \multirow[t]{2}{*}{2006} & KH. Turaichan & $12^{\circ} 13^{\prime} 17.95^{\prime \prime}$ & \multirow{3}{*}{$\begin{array}{c}\text { Selasa } \\
\text { Wage }\end{array}$} & \multirow[t]{3}{*}{$24 / 10 / 2006$} \\
\hline & Sirril Wafa & $11^{\circ} 8^{\prime} 17^{\prime \prime}$ & & \\
\hline Info & Difference & $1^{\circ} 5^{\prime} 0.95^{\prime \prime}$ & & \\
\hline \multirow[t]{2}{*}{2007} & KH. Turaichan & $13^{\circ} 1^{\prime} 11.84^{\prime \prime}$ & \multirow{3}{*}{$\begin{array}{l}\text { Sabtu } \\
\text { Pon }\end{array}$} & \multirow[t]{3}{*}{$13 / 10 / 2007$} \\
\hline & Sirril Wafa & $11^{\circ} 56^{\prime} 67^{\prime \prime}$ & & \\
\hline Info & Difference & $1^{\circ} 4^{\prime} 4.84^{\prime \prime}$ & & \\
\hline \multirow[t]{2}{*}{2011} & KH. Turaichan & $3^{\circ} 02^{\prime} 44.65^{\prime \prime}$ & \multirow{3}{*}{$\begin{array}{c}\text { Rabu } \\
\text { Legi }\end{array}$} & \multirow[t]{3}{*}{$31 / 08 / 2011$} \\
\hline & Sirril Wafa & $2^{\circ} 02^{\prime} 11^{\prime \prime}$ & & \\
\hline Info & Difference & $1^{\circ} 0^{\prime} 33.65^{\prime \prime}$ & & \\
\hline
\end{tabular}

Month of Ramạ̣ān

Table 5.

Comparison of Hisāb's Results in the Month of Ramaḍān

\begin{tabular}{|c|c|c|c|c|}
\hline Year & Version & $\begin{array}{c}\text { High Hilāl } 1 \\
\text { Ramaḍān }\end{array}$ & Day & Date \\
\hline $2012 /$ & KH. Turaichan & $2^{\circ} 47^{\prime} 56.03^{\prime \prime}$ & \multirow{3}{*}{$\begin{array}{l}\text { Sabtu } \\
\text { Legi }\end{array}$} & \multirow[t]{3}{*}{$21 / 7 / 2012$} \\
\hline 1433 & Sirril Wafa & $1^{\circ} 53^{\prime}$ & & \\
\hline Info & Difference & $0^{\circ} 54^{\prime} 56.03^{\prime \prime}$ & & \\
\hline 2013/ & KH. Turaichan & $1^{\circ} 37^{\prime} 28.04^{\prime \prime}$ & \multirow{3}{*}{$\begin{array}{c}\text { Rabu } \\
\text { Kliwon }\end{array}$} & \multirow[t]{3}{*}{$10 / 7 / 2013$} \\
\hline 1434 & Sirril Wafa & $00^{\circ} 50^{\prime} 57^{\prime \prime}$ & & \\
\hline Info & Difference & $0^{\circ} 46^{\prime} 31.04^{\prime \prime}$ & & \\
\hline $2014 /$ & KH. Turaichan & $12^{\circ} 28^{\prime} 11.59^{\prime \prime}$ & \multirow{3}{*}{$\begin{array}{l}\text { Ahad } \\
\text { Wage }\end{array}$} & \multirow[t]{3}{*}{$29 / 6 / 2014$} \\
\hline 1435 & Sirril Wafa & $11^{\circ} 24^{\prime}$ & & \\
\hline Info & Difference & $1^{\circ} 4^{\prime} 11.59^{\prime \prime}$ & & \\
\hline
\end{tabular}

The Month of Dhulhijjah

Table 6.

Comparison of the Results of Hisāb in the Month of Dhulhijjah

\begin{tabular}{ccccc}
\hline \multirow{2}{*}{ Year } & Version & $\begin{array}{c}\text { High Hilāl 1 } \\
\text { Ramaḍān }\end{array}$ & Year & Date \\
\cline { 1 - 3 } $2012 /$ & KH. Turaichan & $12^{\circ} 31^{\prime} 43.21^{\prime \prime}$ & $\begin{array}{c}\text { Jum'at } \\
\text { Pon }\end{array}$ & $26 / 09 / 2014$ \\
\cline { 2 - 3 } 1433 & Sirril Wafa & $1^{\circ} 26^{\prime}$ & \\
\cline { 2 - 3 } Info & Difference & $1^{\circ} 5^{\prime} 43.21^{\prime \prime}$ & \\
\hline
\end{tabular}

122 || Vol 29, No 1, April 2019

AL-AHKAM 
From the Table 6 the comparison of the results of hisāb in Dhulhijjah month between the Almanak Menara Kudus in the era of KH. Turaichan and the Sirril Wafa era have a difference of about $1^{\circ}$.

Then the author compares the results of the hisāb Almanak Menara Kudus in the era of KH. Turaichan with the Sirril Wafa era using contemporary hisāb parameters, namely ephemeris with higher accuracy. The comparative standard is ephemeris because hisāb is contemporary hisāb which is widely used by the astronomers, especially Indonesian celestial experts. So that this hisāb is worthy of being used as a parameter to measure hisāb, including the Almanak Menara Kudus, both in the era of KH. Turaichan and the era of its successors.

Here the author will compare whether there have been significant changes from Almanak Menara Kudus from the era of KH. Turaichan (1990-1999) to the Sirril Wafa era (2000-2019) using contemporary hisāb calculations, namely ephemeris as the parameter. Here the author will analyze the calendar from 1990-2019 (30 years) using random sampling with a span of 5 years. The results are in certain years such as in 1990, 1994 and 1999 in the era of KH. Turaichan and in 2004, 2009, 2014 and 2019 at Sirril Wafa.

\section{The Month of Ramadān}

Comparison of the initial results of Ramadān 1990/1410 H to 2019/ $1440 \mathrm{H}$ between Almanak Menara Kudus (AMK) and Ephemeris with Central Java Headquarters (Semarang), are $-7^{\circ} 0$ 'and $110^{\circ} 24^{\prime}$. It can be seen that in the era of KH. Turaichan in the month of Ramadiann using a simple calculation, such as the height of the moon on the 1st of Ramadān is $5.20 / 100 \mathrm{Dr}$, that means $5^{\circ}$ and $20 / 100 \times 60=12$ minutes. So, $5.20 / 100 \mathrm{Dr}$ is equal to $5^{\circ} 12^{\prime}$. In the era of KH. Turaichan, he also never included ijtimā' either day, date or hour because he was worried that reference would be used by the community.

From the comparison table of the initial Ramadiann hisāb results, the standard ephemeris parameter indicates that the results of the moon's height difference between the Almanak Menara Kudus in the Era of KH.Turaichan and Ephemeris adrift in 1990 were $1^{\circ} 44^{\prime} 59.98^{\prime}$, for 1994 adhering to $1^{\circ} 49^{\prime} 5.94^{\prime \prime}$ and 1999 was $1^{\circ} 48^{\prime 7} 7.79 "$ adrift. Whereas for Mukūth hilāl the difference in 1990 was 7 minutes adrift, for 19948 minutes adrift and 19998 minutes adrift. For the Azimuth hiläl in 1990 it was $0^{\circ} 15^{\prime} 9.95^{\prime \prime}$ adrift, for 1994 it was $0^{\circ}$ $12^{\prime} 9.96 "$ adrift and 1999 was $0^{\circ} 14^{\prime} 59.97 "$ "adrift. 
While the comparison of the results of hisāb for Ramadān's early month height between Almanak Menara Kudus in the successor era of KH. Turaichan and ephemeris was $0^{\circ} 39^{\prime} 59.99^{\prime \prime}$, for 2009 adrift $0^{\circ} 47^{\prime} 59.94^{\prime \prime} 2014$ was $0^{\circ} 37^{\prime}$ 59.98" and 2019 is $0^{\circ} 12^{\prime} 22.27^{\prime \prime}$ adrift. Whereas for Muküth hilāl the difference in 2004 did not exist because in the Holy Almanac there was no mention, for 20098 minutes adrift, 2014 was 9 minutes adrift, and 2019 was 6 minutes adrift. For the 2004 Azimuth hilāl to be $0^{\circ} 11^{\prime} 59.96 "$ ", for $20090^{\circ} 30^{\prime} 59.98 "$ adrift in 2014 was $0^{\circ} 49^{\prime} 11.97 "$ and 2019 was $0^{\circ} 11^{\prime} 40.25^{\prime \prime}$ adrift.

From the results of these comparisons, it can be seen that the height difference of the month for the AMK era of KH. Turaichan is almost $2^{\circ}$, while the AMK era of successor KH. Turaichan has a difference of around $1 / 2^{\circ}$. For Muküth hilāl, the AMK era of KH. Turaichan with AMK the successor era, the difference is almost the same. As for the Azimuth hilāl the difference is not much different.

\section{High hiläl in the month of Ramadān}

High Comparison of the hilāl AMK era of KH. Turaichan and Sirril Wafa Era with Ephemeris parameters for the months of Ramaḍān in 1990-2019, are in 1990, 1994 and 1999 in the era of KH. Turaichan and 2004, 2009 and 2019 in Sirril Wafa.

Table 7.

\section{Hilāl Ramaḍān High Comparison}

\begin{tabular}{cccc}
\hline \multirow{2}{*}{$\begin{array}{c}\text { 1 Ramad̄ān } \\
\text { Year }\end{array}$} & $\begin{array}{c}\text { Difference High Hilāl } \\
\text { Turaichan }\end{array}$ & $\begin{array}{c}\text { The next era } \\
\text { (Sirril Wafa) }\end{array}$ & $\begin{array}{c}\text { Difference } \\
\text { Comparisson with } \\
\text { ephemeris } \\
\text { paramater }\end{array}$ \\
\cline { 2 - 3 } & $1^{\circ} 44^{\prime} 59.98^{\prime \prime}$ & - & $1^{\circ} 44^{\prime} 59.98^{\prime \prime}$ \\
\hline $1990 / 1410$ & $1^{\circ} 49^{\prime} 5.94^{\prime \prime}$ & - & $1^{\circ} 49^{\prime} 5.94^{\prime \prime}$ \\
\hline $1994 / 1414$ & $1^{\circ} 48^{\prime} 7.79^{\prime \prime}$ & - & $1^{\circ} 48^{\prime} 7.79^{\prime \prime}$ \\
\hline $1999 / 1420$ & - & $0^{\circ} 39^{\prime} 59.99^{\prime \prime}$ & $0^{\circ} 39^{\prime} 59.99^{\prime \prime}$ \\
\hline $2004 / 1425$ & - & $0^{\circ} 47^{\prime} 59.94^{\prime \prime}$ & $0^{\circ} 47^{\prime} 59.94^{\prime \prime}$ \\
\hline $2009 / 1430$ & - & $0^{\circ} 37^{\prime} 59.98^{\prime \prime}$ & $0^{\circ} 37^{\prime} 59.98^{\prime \prime}$ \\
\hline $2014 / 1435$ & - & $0^{\circ} 12^{\prime} 22,27^{\prime \prime}$ & $0^{\circ} 12^{\prime} 22,27^{\prime \prime}$ \\
\hline $2019 / 1440$ & & & \\
\hline
\end{tabular}


In the Table 7, it can be seen that the smallest difference value lies in 2019 which is worth $0^{\circ} 12^{\prime} 22.27 "$, while the one with the greatest difference in value is in 1994 which is equal to $1^{\circ} 49^{\prime} 5.94 "$.

\section{Mukūth Hilāl in the month of Ramaḍān}

The comparison of Mukūth Hilāl AMK era of KH. Turaichan and its successor Era with Ephemeris parameters for Shawwāl months 1990-2019 are in 1990, 1994 and 1999 in the era of KH. Turaichan and 2004, 2009, 2014 and 2019 in Sirril Wafa.

Table 8.

Comparison of Mukūth Hilāl in the month of Ramaḍān

\begin{tabular}{cccc}
\hline \multirow{2}{*}{$\begin{array}{c}\text { Ramaḍan } \\
\text { Year }\end{array}$} & $\begin{array}{c}\text { Era KH. } \\
\text { Turaichan }\end{array}$ & $\begin{array}{c}\text { The next era } \\
\text { (Sirril Wafa) }\end{array}$ & $\begin{array}{c}\text { Difference } \\
\text { Comparisson with } \\
\text { ephemeris } \\
\text { parameter }\end{array}$ \\
\cline { 2 - 4 } & 7 & - & 7 \\
\hline $1990 / 1410$ & 8 & - & 8 \\
\hline $1994 / 1414$ & 8 & - & 8 \\
\hline $1999 / 1420$ & - & - & - \\
\hline $2004 / 1425$ & - & 8 & 8 \\
\hline $2009 / 1430$ & - & 9 & 9 \\
\hline $2014 / 1435$ & & 6 & 6 \\
\hline $2019 / 1440$ & & & \\
\hline
\end{tabular}

From the Table 8, it can be seen that the smallest difference is located in 2019 which is worth 6 minutes, while the one with the greatest difference in value is in 2014 which is 9 minutes.

\section{Azimuth Hiläl in the month of Ramaḍan}

The comparison of Azimuth Hilāl AMK era of KH. Turaichan and its successor Era with Ephemeris parameters for Shawwāl months 1990-2018 which were 1990, 1994 and 1999 in the era of KH. Turaichan and 2004, 2009 and 2014 at Sirril Wafa.

From the Table 9, it can be seen that the smallest difference in value is in 2019 which is worth $0^{\circ} 11^{\prime} 40.25^{\prime \prime}$, while the one with the largest difference in value is in 2014 which is $0^{\circ} 49^{\prime} 11.97 "$. 
Table 9.

Comparison of Azimuth Hilāl in the month of Ramadān

\begin{tabular}{cccc}
\hline \multirow{2}{*}{$\begin{array}{c}\text { 1 Ramaḍan } \\
\text { Year }\end{array}$} & $\begin{array}{c}\text { Era KH. } \\
\text { Turaichan }\end{array}$ & $\begin{array}{c}\text { The next era } \\
\text { (Sirril Wafa) }\end{array}$ & $\begin{array}{c}\text { Difference } \\
\text { Comparisson with } \\
\text { ephemeris } \\
\text { parameter }\end{array}$ \\
\cline { 2 - 3 } & $0^{\circ} 15^{\prime} 9,95^{\prime \prime}$ & - & $0^{\circ} 15^{\prime} 9,95^{\prime \prime}$ \\
\hline $1990 / 1410$ & $0^{\circ} 12^{\prime} 9,96^{\prime \prime}$ & - & $0^{\circ} 12^{\prime} 9,96^{\prime \prime}$ \\
\hline $1994 / 1414$ & $0^{\circ} 14^{\prime} 59.97^{\prime \prime}$ & - & $0^{\circ} 14^{\prime} 59.97^{\prime \prime}$ \\
\hline $1999 / 1420$ & - & $0^{\circ} 11^{\prime} 59.96^{\prime \prime}$ & $0^{\circ} 11^{\prime} 59.96^{\prime \prime}$ \\
\hline $2004 / 1425$ & - & $0^{\circ} 30^{\prime} 59,98^{\prime \prime}$ & $0^{\circ} 30^{\prime} 59,98^{\prime \prime}$ \\
\hline $2009 / 1430$ & - & $0^{\circ} 49^{\prime} 11,97^{\prime \prime}$ & $0^{\circ} 49^{\prime} 11,97^{\prime \prime}$ \\
\hline $2014 / 1435$ & - & $0^{\circ} 11^{\prime} 40,25^{\prime \prime}$ & $0^{\circ} 11^{\prime} 40,25^{\prime \prime}$ \\
\hline $2019 / 1440$ & & &
\end{tabular}

\section{The Month of Shawwāl}

The comparison of the initial results of Shawwāl 1990/1410 H to 2014/1435 H between the Almanac Menara Kudus (AMK) and Ephemeris with Central Java Headquarters (Semarang), are $-7^{\circ} 0^{\prime}$ and $110^{\circ} 24$ '. It shows that the height of the moon between Almanak Menara Kudus in the KH. Turaichan era and Ephemeris in 1990 was $1^{\circ} 46^{\prime} 7.99 "$ adrift, for $19941^{\circ} 45^{\prime}$ 59.98" adhered and 1999 was $1^{\circ} 50^{\prime}$ 59.98". Whereas for Mukūth hilāl the difference in 1990 was 44 minutes adrift, for 19947 minutes adrift and 19999 minutes adrift. For the Azimuth hilāl in 1990 1² 21' 39.97" was adrift, for 1994 $0^{\circ} 10^{\prime} 39.99 "$ "was adrift and 1999 was $0^{\circ}$ 9' 29.95" adrift.

While the comparison of the results of hisāb for Ramadān's initial month height between Almanak Menara Kudus of the successor era of KH. Turaichan and ephemeris was in $20044^{\circ} 18^{\prime} 59.97^{\prime \prime}$, for 2009 adrift $0^{\circ} 41^{\prime} 31.99^{\prime \prime}, 2014$ was $0^{\circ} 37^{\prime}$ adrift $0^{\prime \prime}$, and 2019 is $0^{\circ} 23^{\prime} 00^{\prime \prime}$ adrift. Whereas for Mukūth hilāl the difference in 2004 did not exist because in Almanak Menara Kudus there was no mention, for 20098 minutes adrift, 2014 was 8 minutes adrift and 2019 was 3 minutes adrift. For the Azimuth hilāl in 2004 it was $0^{\circ} 52^{\prime} 0.04 "$ ", for 2009 it was $0^{\circ} 20^{\prime} 0.01$ " adrift, 2014 was $0^{\circ} 13^{\prime} 59.99 "$ and 2019 was $4^{\circ} 34^{\prime} 20.8^{\prime \prime}$ adrift.

\section{High hiläl in the month of Shawwal}

High Comparison of the hilāl AMK in the era of KH. Turaichan and the Sirril Wafa era with Ephemeris parameters for the month of Shawāl in 1990-2018, 
are in 1990, 1994 and 1999 in the era of KH. Turaichan and 2004, 2009 and 2014 at Sirril Wafa.

From the Table 10, it can be seen that the smallest difference value lies in 2019 which is worth $0^{\circ} 23^{\prime} 00^{\prime \prime}$, while the one with the greatest difference in value is in 2004 which is $4^{\circ} 18^{\prime} 59.97^{\prime \prime}$.

Table 10.

High Comparison of the hilāl in the month of Shawwāl

\begin{tabular}{cccc}
\hline \multirow{2}{*}{$\begin{array}{c}\text { Shawwāl } \\
\text { Year }\end{array}$} & $\begin{array}{c}\text { Era KH. } \\
\text { Turaichan }\end{array}$ & $\begin{array}{c}\text { Hhe next era } \\
\text { (Sirril Wafa) }\end{array}$ & $\begin{array}{c}\text { Difference } \\
\text { Comparisson with } \\
\text { ephemeris } \\
\text { parameter }\end{array}$ \\
\cline { 2 - 4 } & $1^{\circ} 46^{\prime} 7.99^{\prime \prime}$ & - & $1^{\circ} 46^{\prime} 7.99^{\prime \prime}$ \\
\hline $1990 / 1410$ & $1^{\circ} 45^{\prime} 59.98^{\prime \prime}$ & - & $1^{\circ} 45^{\prime} 59.98^{\prime \prime}$ \\
\hline $1994 / 1414$ & $1^{\circ} 50^{\prime} 59.98^{\prime \prime}$ & - & $1^{\circ} 50^{\prime} 59.98^{\prime \prime}$ \\
\hline $1999 / 1420$ & - & $4^{\circ} 18^{\prime} 59.97^{\prime \prime}$ & $4^{\circ} 18^{\prime} 59.97^{\prime \prime}$ \\
\hline $2004 / 1425$ & - & $0^{\circ} 41^{\prime} 31.99^{\prime \prime}$ & $0^{\circ} 41^{\prime} 31.99^{\prime \prime}$ \\
\hline $2009 / 1430$ & - & $0^{\circ} 37^{\prime} 0^{\prime \prime}$ & $0^{\circ} 37^{\prime} 0^{\prime \prime}$ \\
\hline $2014 / 1435$ & & $0^{\circ} 23^{\prime} 00^{\prime \prime}$ & $0^{\circ} 23^{\prime} 00^{\prime \prime}$ \\
\hline $2019 / 1440$ & &
\end{tabular}

Table 11.

Comparison of Mukūth Hilāl in the month of Shawwāl

\begin{tabular}{cccc}
\hline \multirow{2}{*}{$\begin{array}{c}\text { Y Shawwāl } \\
\text { Year }\end{array}$} & $\begin{array}{c}\text { Era KH. } \\
\text { Turaichan }\end{array}$ & $\begin{array}{c}\text { The next era } \\
\text { (Sirril Wafa) }\end{array}$ & $\begin{array}{c}\text { Difference } \\
\text { Comparisson with } \\
\text { ephemeris } \\
\text { parameter }\end{array}$ \\
\hline $1990 / 1410$ & 44 & - & 44 \\
\hline $1994 / 1414$ & 7 & - & 7 \\
\hline $1999 / 1420$ & 9 & - & 9 \\
\hline $2004 / 1425$ & - & - & - \\
\hline $2009 / 1430$ & - & 8 & 8 \\
\hline $2014 / 1435$ & - & 8 & 8 \\
\hline $2019 / 1440$ & & 8 & 8 \\
\hline
\end{tabular}


Table 12.

Comparison of Azimuth Hilāl in the month of Shawwāl

\begin{tabular}{cccc}
\hline \multirow{2}{*}{$\begin{array}{c}\text { Y Shawwāl } \\
\text { Year }\end{array}$} & $\begin{array}{c}c \\
\text { Era KH. } \\
\text { Turaichan }\end{array}$ & $\begin{array}{c}\text { The next era } \\
\text { (Sirril Wafa) }\end{array}$ & $\begin{array}{c}\text { Difference } \\
\text { Comparisson with } \\
\text { ephemeris } \\
\text { paramater }\end{array}$ \\
\cline { 2 - 4 } & $1^{\circ} 21^{\prime} 39.97^{\prime \prime}$ & - & $1^{\circ} 21^{\prime} 39.97^{\prime \prime}$ \\
\hline $1990 / 1410$ & $0^{\circ} 10^{\prime} 39.99^{\prime \prime}$ & - & $0^{\circ} 10^{\prime} 39.99^{\prime \prime}$ \\
\hline $1994 / 1414$ & $0^{\circ} 9^{\prime} 29.95^{\prime \prime}$ & - & $0^{\circ} 9^{\prime} 29.95^{\prime \prime}$ \\
\hline $1999 / 1420$ & - & $0^{\circ} 52^{\prime} 0.04^{\prime \prime}$ & $0^{\circ} 52^{\prime} 0.04^{\prime \prime}$ \\
\hline $2004 / 1425$ & - & $0^{\circ} 20^{\prime} 0.01^{\prime \prime}$ & $0^{\circ} 20^{\prime} 0.01^{\prime \prime}$ \\
\hline $2009 / 1430$ & - & $0^{\circ} 13^{\prime} 59.99^{\prime \prime}$ & $0^{\circ} 13^{\prime} 59.99^{\prime \prime}$ \\
\hline $2014 / 1435$ & & $4^{\circ} 34^{\prime} 20,8^{\prime \prime}$ & $4^{\circ} 34^{\prime} 20,8^{\prime \prime}$ \\
\hline $2019 / 1440$ & & & \\
\hline
\end{tabular}

\section{Mukūth Hilāl in the month of Shawwāl}

The comparison of Mukūth Hilāl AMK era of KH. Turaichan and its successor era with Ephemeris parameters for Shawwāl months 1990-2018, are in 1990, 1994 and 1999 in the era of KH. Turaichan and 2004, 2009 and 2014 at Sirril Wafa.

Based on the Table 11, it can be seen that the smallest difference value lies in 1994 which is worth 7 minutes, while the one with the greatest difference is found in 1990, which is 44 minutes.

\section{Azimuth Hiläl in the month of Shawwal}

The comparison of Muküth Hilāl AMK in the era of KH. Turaichan and its successor era with Ephemeris parameters for Shawwāl months 1990-2019, are in 1990, 1994 and 1999 in the era of KH. Turaichan and 2004, 2009, 2014 and 2019 at Sirril Wafa.

From the Table 12, it can be seen that the smallest difference in value is in 1999 , which is worth $0^{\circ} 9^{\prime} 29.95^{\prime \prime}$, while the one with the greatest difference is in 2019 , which is $4^{\circ} 34^{\prime} 20.8^{\prime \prime}$.

\section{The Month of Dhulhijjah}

The comparison of the results of the beginning of Dhulhijjah 1990/1410H to 2014/1435H between Almanak Menara Kudus (AMK) and Ephemeris with the 
Central Java Headquarters (Semarang) ie $-7^{\circ} 0^{\prime}$ and $110^{\circ} 24^{\prime}$ indicates that the height of the moon is between Almanak Menara Kudus in the of Era KH. Turaichan with Ephemeris in 1990 had a difference of 1० 46' 6", for 1994 the difference was $1^{\circ} 38^{\prime} 5.99 "$ and in 1999 the difference was $1^{\circ} 53^{\prime}$ 5.97". Whereas for Mukūth hilāl the difference in 1990 was 11 minutes adrift, for 1994 the difference was 9 minutes and 1999 was 10 minutes adrift. For the Azimuth hilāl in 1990 the difference was $0^{\circ} 51^{\prime} 9.96 "$ ", for 1994 the difference was $0^{\circ} 32^{\prime} 9.98 "$ and 1999 in the AMK era of KH. Turaichan did not include.

While reversing the results of hisāb for the height of the early month of Dhulhijjah between the Almanak Menara Kudus of the successor era of $\mathrm{KH}$. Turaichan and ephemeris is based on 2004 the difference is $0^{\circ} 41^{\prime} 59,97^{\prime \prime}$, for $0^{\circ}$ $43^{\prime} 1.98^{\prime \prime}$ in 2014 the difference is $0^{\circ} 38^{\prime} 59,95^{\prime \prime}$ and 2019 the difference is $0^{\circ} 3^{\prime}$ 33.43". Whereas for Mukūth hilāl the difference in 2004 did not exist because in the Holy Almanac it was not mentioned, for 2009 the difference was 11 minutes, 2014 was 6 minutes adrift and 2019 the difference was. 5 minutes for the Azimuth of the new moon in 2004 the difference is $0^{\circ} 4{ }^{\prime} 59,98^{\prime \prime}$ for 2009 the difference is $0^{\circ} 6^{\prime} 59,96 "$ ", in 2014 the difference is $0^{\circ} 2^{\prime} 23,97 "$ and in 2019 the difference is $0^{\circ} 11^{\prime} 14,31^{\prime \prime}$.

\section{High hilāl in the month of Dhulhijjah}

High Comparison of the hilāl AMK in the era of KH. Turaichan and the Sirril Wafa era with Ephemeris parameters for the month of Shawwāl in 1990-2019, are in 1990, 1994 and 1999 in the era of KH. Turaichan and 2004, 2009, 2014 and 2019 at Sirril Wafa.

Table 13.

High comparison of the hiläl in the month of Dhulhijjah

\begin{tabular}{cccc}
\hline \multirow{2}{*}{$\begin{array}{c}\text { Dhulhijjah } \\
\text { Year }\end{array}$} & $\begin{array}{c}\text { Era KH. } \\
\text { Turaichan }\end{array}$ & $\begin{array}{c}\text { The next era } \\
\text { (Sirril Wafa) }\end{array}$ & $\begin{array}{c}\text { Difference } \\
\text { Comparisson with } \\
\text { ephemeris } \\
\text { paramater }\end{array}$ \\
\cline { 2 - 4 } & $1^{\circ} 46^{\prime} 6^{\prime \prime}$ & - & $1^{\circ} 46^{\prime} 6^{\prime \prime}$ \\
\hline $1990 / 1410$ & $1^{\circ} 38^{\prime} 5.99^{\prime \prime}$ & - & $1^{\circ} 38^{\prime} 5.99^{\prime \prime}$ \\
\hline $1994 / 1414$ & $1^{\circ} 53^{\prime} 5.97^{\prime \prime}$ & - & $1^{\circ} 53^{\prime} 5.97^{\prime \prime}$ \\
\hline $1999 / 1419$ & - & $0^{\circ} 41^{\prime} 59.97^{\prime \prime}$ & $0^{\circ} 41^{\prime} 59.97^{\prime \prime}$ \\
\hline $2004 / 1424$ & - & $0^{\circ} 43^{\prime} 1.98^{\prime \prime}$ & $0^{\circ} 43^{\prime} 1.98^{\prime \prime}$ \\
\hline $2009 / 1430$ & - & $0^{\circ} 38^{\prime} 59.95^{\prime \prime}$ & $0^{\circ} 38^{\prime} 59.95^{\prime \prime}$ \\
\hline $2014 / 1435$ & - & $0^{\circ} 3^{\prime} 33,43^{\prime \prime}$ & $0^{\circ} 3^{\prime} 33,43^{\prime \prime}$ \\
\hline $2019 / 1440$ & - & & \\
\hline
\end{tabular}


Based on the Table 13, it can be seen that the smallest difference in value is in 2019 which is worth $0^{\circ} 3^{\prime} 33.43^{\prime \prime}$, while the one with the highest difference value is in 1999 which is equal to $1^{\circ} 53^{\prime} 5.97^{\prime \prime}$.

\section{Mukūth Hilāl in the month of Dhulhïjah}

High Comparison of the hilāl AMK in the era of KH. Turaichan and the Sirril Wafa era with Ephemeris parameters for Shawwāl months 1990-2019, are in 1990, 1994 and 1999 in the era of KH. Turaichan and 2004, 2009, 2014 and 2019 at Sirril Wafa.

Table 14.

\section{Comparison of Mukūth Hiläl in the month of Dhulhịjjah}

\begin{tabular}{cccc}
\hline \multirow{2}{*}{$\begin{array}{c}\text { 1 Dhulhijjah } \\
\text { Year }\end{array}$} & \begin{tabular}{c} 
Era \\
\cline { 2 - 4 }
\end{tabular} & $\begin{array}{c}\text { The next era } \\
\text { (Sirril Wafa) }\end{array}$ & $\begin{array}{c}\text { Difference } \\
\text { Comparisson with } \\
\text { ephemeris } \\
\text { paramater }\end{array}$ \\
\hline $1990 / 1410$ & 11 & - & 11 \\
\hline $1994 / 1414$ & 9 & - & 9 \\
\hline $1999 / 1420$ & 10 & - & 10 \\
\hline $2004 / 1425$ & - & - & - \\
\hline $2009 / 1430$ & - & 11 & 11 \\
\hline $2014 / 1435$ & - & 6 & 5 \\
\hline $2019 / 1440$ & - & 5 & \\
\hline
\end{tabular}

From the table above, it can be seen that the smallest difference is located in 2019 which is worth 5 minutes while the one with the highest difference is found in 1990 and 2014 which is 11 minutes.

\section{Azimuth Hilāl in the month of Dhulhijjah}

High Comparison of the hilāl AMK in the era of KH. Turaichan and the Sirril Wafa era with Ephemeris parameters for Shawwāl months 1990-2019, are in 1990, 1994 and 1999 in the era of KH. Turaichan and 2004, 2009, 2014 and 2019 at Sirril Wafa. 
Table 15.

Comparison of Azimuth Hiläl in the month of Dhulhịjjah

\begin{tabular}{cccc}
\hline \multirow{2}{*}{$\begin{array}{c}\text { 1 Dhulhijjah } \\
\text { Year }\end{array}$} & $\begin{array}{c}\text { Era KH. } \\
\text { Turaichan }\end{array}$ & $\begin{array}{c}\text { Era Next (Sirril } \\
\text { Wafa) }\end{array}$ & $\begin{array}{c}\text { Difference } \\
\text { Comparisson with } \\
\text { ephemeris } \\
\text { paramater }\end{array}$ \\
\hline $1990 / 1410$ & $0^{\circ} 51^{\prime} 9.96^{\prime \prime}$ & - & $0^{\circ} 51^{\prime} 9.96^{\prime \prime}$ \\
\hline $1994 / 1414$ & $0^{\circ} 32^{\prime} 9.98^{\prime \prime}$ & - & $0^{\circ} 32^{\prime} 9.98^{\prime \prime}$ \\
\hline $1999 / 1420$ & - & - & - \\
\hline $2004 / 1425$ & - & $0^{\circ} 4^{\prime} 59.98^{\prime \prime}$ & $0^{\circ} 4^{\prime} 59.98^{\prime \prime}$ \\
\hline $2009 / 1430$ & - & $0^{\circ} 6^{\prime} 59.96^{\prime \prime}$ & $0^{\circ} 6^{\prime} 59.96^{\prime \prime}$ \\
\hline $2014 / 1435$ & - & $0^{\circ} 2^{\prime} 23.97^{\prime \prime}$ & $0^{\circ} 2^{\prime} 23.97^{\prime \prime}$ \\
\hline $2019 / 1440$ & - & $0^{\circ} 11^{\prime} 14,31^{\prime \prime}$ & $0^{\circ} 11^{\prime} 14,31^{\prime \prime}$ \\
\hline
\end{tabular}

From the data above, it can be seen that the smallest difference in value is in 2014 which is worth $0^{\circ} 2^{\prime} 23.97 "$, while the one with the largest difference in value is in 1990 at $0^{\circ} 51^{\prime} 9.96 "$.

From the comparison table, the results of the initial hisāb of Dhulhijjah the standard parameters of Ephemeris show that the results between Almanak Menara Kudus and Ephemeris are only a few minutes adrift, and that is normal because each hisāb will certainly produce different calculations.

So, after analyzing using the Ephemeris system comparison, it can be seen that the difference between the Almanak Menara Kudus and Ephemeris is very small. The difference between the era of KH. Turaichan and the Sirril Wafa era was also very small because in the Sirril Wafa era had corrections. This shows that the reckoning system in the Almanak Menara Kudus (hisāb haqiq $\bar{\imath}$ bi tahqiq $\bar{\imath}$ ) has accurate accuracy that is not much different from the reckoning system used in modern reckoning systems, namely Ephemeris.

\section{Conclusion}

In this section, the important points are the conclusions of what the author has explained in the section above. The results are as follows: the comparison of the results of hisāb in the Almanak Menara Kudus (AMK) between the era of KH. Turaichan and the Sirril Wafa era from 1990-2019 are: 
Ahmad Fauzi

The method in Almanak Menara Kudus hisāb in the era of KH. Turaichan is viewed in terms of astronomical data and hisāb hilāl includes hisāb haqĩ tahqīq $\bar{\imath}$ using a transplanting data of the book Mațla' al-Sa'îd with the process of al-Khulāsah al-Wäfiyyah and its epoch Semarang Central but not using correction hilāl mar'ī. While Almanak Menara Kudus in the Sirril Wafa era still uses the same data and epoch but there are developments with added corrections namely horizontal parallax, refraction, and semi-moon diameter (SD) so that the results of the hisāb are more accurate.

Comparison of the results of hisāb between the era of $\mathrm{KH}$. Turaichan and the Sirril Wafa era for the months of Shawwāl, Ramadān and Dhulhijjah is a difference of $\pm 1^{\circ}$ because there are corrections in the Sirril era.

The results of hisāb for the month of Ramaḍān, the high yield of the hilāl with the ephemeris parameter gets the smallest difference value located in 2019 which is worth $0^{\circ} 12^{\prime} 22.27^{\prime \prime}$, while the one with the highest difference value is in 1994 which is $1^{\circ} 49^{\prime}$ 5.94". Shawwāl, the highest yield of hilāl gets the smallest difference value located in 2019 which is worth $0^{\circ} 23^{\prime} 00^{\prime \prime}$, while the one with the greatest difference in value is in 2004 which is $4^{\circ} 18^{\prime} 59.97^{\prime \prime}$. Hijriyah, the highest yield of hilāl gets the smallest difference value located in 2019 which is worth $0^{\circ} 3^{\prime} 33.43^{\prime \prime}$, the year which has the greatest difference in value is in 1999 which is equal to $1^{\circ} 53^{\prime} 5.97 " .[\mathrm{a}]$

\section{BIBLIOGRAPHY}

Ade Mansur, Muslih. Belajar Ilmu Falak 2. Cilacap: Ihya Media, 2011.

Azhari, Susiknan. Hisab \& Rukyah (Wacana untuk Membangun Kebersamaan di Tengah Perbedaan). Yogyakarta: Pustaka Pelajar, 2007.

Depdiknas. Kamus Besar Bahasa Indonesia. Jakarta: Pusat Bahasa, 2008.

Ghazali, Ahmad. al-Dur al-'Aniq, fi Ma'rifah al-Hilāl wa al-Khusufayn bi alTadqīq. Madura: Lafal Lanbulan, n.d.

Hambali, Slamet. Almanak Sepanjang Masa Sejarah Sistem Penanggalan Masehi, Hijriyah dan Jawa. Semarang: Program Pasca Sarjana IAIN Walisongo, 2002.

al-Jailani, Zubair Umar. al-Khulāșah al-Wāfiyyah fi al-Falak bi Jadwāl alLugharitmiyah. Surakarta: Melati, n.d. 
Juli Rakhmadi Butar-butar, Arwin. Kalender Sejarah dan Arti Pentingnya dalam Kehidupan. Semarang: Bisnis Mulia Konsultama, 2014.

Kemenag. Ephemeris Hisab Rukyat 2014. Jakarta: Kemenag RI, 2014.

Mujab, Syaiful."Konsep Penentual Awal Bulan Hijriyah Menurut KH. Turaichan Adjuri." Pasca IAIN Walisongo, 2010.

Nawawi, Abd Salam. Ilmu Astronomy Cara Menghitung Waktu Salat Arah Kiblat dan Awal Bulan. Sidoarjo: Aqaba, 2010.

"Sang Penerus Falak yang Kharismatik dari Kota Santri," 2015. 
